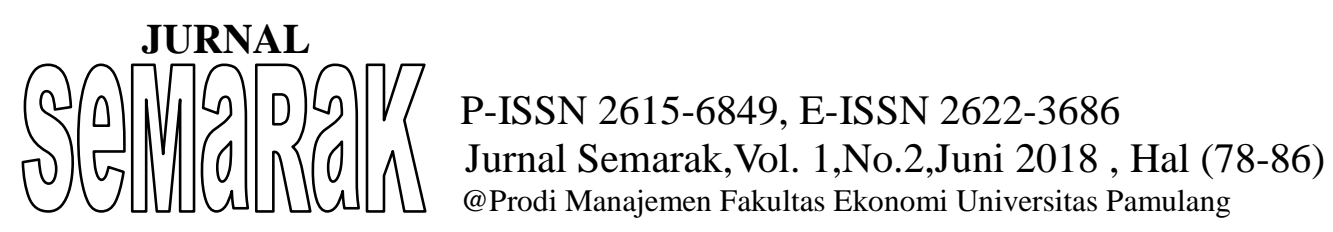

\title{
PENGARUH BUDAYA ORGANISASI TERHADAP KINERJA GURU PADA SEKOLAH DASAR NEGERI O6 CIPUTAT
}

\author{
Komarudin $^{1)}$ \\ dosen universitas pamulang, email : komarudin_101263@yahoo.com
}

\begin{abstract}
Abstrak
Penelitian ini dilatar belakangi karena budaya organisasi yang ada pada Sekolah Dasar Negeri 06 Ciputat belum terlaksana secara baik dalam konteks manajemen sekolah semua kegiatan sekolah harus dikelola dengan memanfaatkan semua sumber daya yang ada untuk mencapai tujuan secara efektif dan efisien pada Sekolah Dasar Negeri 06 Ciputat.

Metode yang digunakan dalam penelitian ini menggunakan metode kuantitatif dan data yang diperoleh dari kuesioner dengan jumlah responden 50 orang guru Sekolah Dasar Negeri 06 Ciputat dan dianalisis secara manual dan dibantu dengan menggunakan program Microsoft Excel 2007 dengan pengujian instrument penelitian Uji Validitas, Uji Reliabilitas, Analisis Korelasi Sederhana, Koefisien Determinasi, Uji Regresi Linear Sederhana, Uji Hipotesis T (parsial).

Berdasarkan hasil penelitian uji analisis korelasi sederhana yang dilakukan didapati hubungan yang kuat antara budaya organisasi dan kinerja guru, sedangkan hasil penelitian koefisien determinasi dengan kontribusi sebesar 40,2\% dan selebihnya yaitu 59,8\% dipengaruhi oleh beberapa faktor lain dan berdasarkan penelitian menggunakan uji regresi linier sederhana didapati hasil $\hat{y}=13,53+0,661(X)$. Dengan nilai $t_{\text {hitung }}$ sebesar 5,875 lebih besar dari $t_{\text {tabel }}$ sebesar 2,010 yang artinya bahwa terdapat pengaruh yang signifikan antara budaya organisasi terhadap kinerja guru.
\end{abstract}

\section{Kata Kunci : Budaya Organisasi, Kinerja.}

\section{Abstract}

This study is based on the existing organizational culture at the State Elementary School 06 Ciputat has not been implemented well in the context of school management all school activities must be managed by utilizing all the resources available to achieve the goal effectively and efficiently at the State Elementary School 06 Ciputat.

The method used in this study using quantitative methods and data obtained from the questionnaire with the number of respondents 50 teachers of elementary school 06 Ciputat and analyzed manually and assisted by using the program Microsoft Excel 2007 with testing instrument research Test Validity, Reliability Test, Correlation Analysis Simple, Coefficient of Determination, Simple Linear Regression Test, Hypothesis T Test (partial).

Based on the results of research, simple correlation analysis performed found a strong relationship between organizational culture and teacher performance, while the results of coefficient of determination research with a contribution of $40.2 \%$ and the rest of $59.8 \%$ is influenced by several other factors and based on research using regression test Simple linear results obtained $\hat{y}=13.53+0.661(X)$. With the tcount of 5.875 is greater than the ttable of 2.010 which means that there is a significant influence between organizational culture on teacher performance.

Keywords: Organizational Culture, Performance. 


\section{Pendahuluan}

\section{A. Latar Belakang}

Di dalam dunia pendidikan tidak terlepas dari peran guru disekolah, karena sekolah merupakan suatu organisasi yang menghubungkan langsung antara guru dan siswa, adapun usaha-usaha yang dilakukan untuk meningkatkan mutu dari suatu sekolah diantaranya yaitu peningkatan kurikulum, peningkatan kemampuan guru, peningkatan kemampuan kepala sekolah, peningkatan kemampuan pendukungnya, peningkatan sarana prasarana dan peningkatan manajemen serta organisasi sekolah. Sekolah sebagai satuan pendidikan yang menyelenggarakan kegiatan belajar mengajar merupakan bagian dari pendidikan yang berjenjang dan berkesinambungan. Di era orde baru sekolah merupakan unit subordinat dalam sebuah struktur organisasi besar dengan otonomi yang sangat terbatas.

Berbagai penelitian menunjukkan bahwa selama ini, walaupun telah mengalami berbagai fase perubahan kurikulum yang dibarengi dengan berbagai macam peraturan perundangan, masih saja kualitas pendidikan belum seperti yang diharapkan. Terutama jika dilihat dari prestasi yang dibandingkan dengan prestasi pendidikan bangsa-bangsa lain. Hal ini bisa dilihat dari Indeks Pertumbuhan Manusia (Human Development Indeks) bahwa Indonesia masih berada diatas angka 100 dari 187 negara didunia, pada tahun 2014 misalnya, Indonesia memasuki peringkat ke 108. Peringkat ini terpaut jauh dengan negaranegara lainnya.

Menurut Maryati (2015:3) dalam data Kementrian Pendidikan Nasional (Kemendiknas) menunjukkan, ketidaksesuaian ilmu guru dengan pelajaran yang diampunya banyak ditemui pada jenjang sekolah menengah atas (SMA). Sekitar 49,24\% guru SMA dalam kondisi seperti itu. (total 252.947 guru). Urutan kedua terjadi pada jenjang SD
Sebanyak 542.002 guru $(34,8 \%)$ dari 1,55 juta guru SD masuk katagori tersebut (Kompas, Selasa 19 Juli 2011).

Namun masalah mutu pendidikan tersebut tidak dapat dibebankan hanya kepada satu pihak, tetapi merupakan tanggung jawab semua pihak yang terlibat secara langsung maupun tidak langsung dalam menyelenggarakan proses pendidikan, seperti lembaga sekolah, perguruan tinggi, pemerintah, masyarakat dan orang tua.

Di sekolah setiap warga sekolah baik kepala sekolah, guru, tenaga

administrasi, siswa, komite sekolah mempunyai tata nilai dan norma tersendiri yang diyakininya, akan tetapi dalam budaya organisasi seseorang dengan latar belakang yang berbeda-beda, pekerjaan yang berbeda mempunyai persepsi yang sama tentang karakteristik sekolah.

Budaya organisasi juga mempengaruhi kinerja guru di dalam organisasi atau lembaga, namun kinerja sumber daya manusia sangat ditentukan oleh kondisi lingkungan internal maupun eksternal organisasi, termasuk budaya organisasi. Budaya organisasi adalah suatu kebiasaan yang telah berlangsung lama dan dipakai serta diterapkan dalam kehidupan aktivitas kerja sebagai salah satu untuk meningkatkan kualitas kerja para pekerja. Jones (2001) dalam Fahmi (2013:47) mendefinisikan kultur organisasi adalah sebagai kumpulan nilai dan norma hasil berbagi yang mengendalikan interaksi anggota organisasi satu sama lain dan dengan orang lain di luar organisasi.

Selain dari permasalahan di atas, yang perlu diperhatikan lagi pada Sekolah Dasar Negeri 06 Ciputat adalah kinerja guru dalam mengajar di sekolah, kinerja guru juga menjadi salah satu hal penting yang harus dimiliki oleh guru sebagai seorang pengajar dan pendidik. Fakta dilapangan yang sering di jumpai disekolah pada umumnya guru-guru tidak hanya mengajar pada satu sekolah saja tetapi harus 


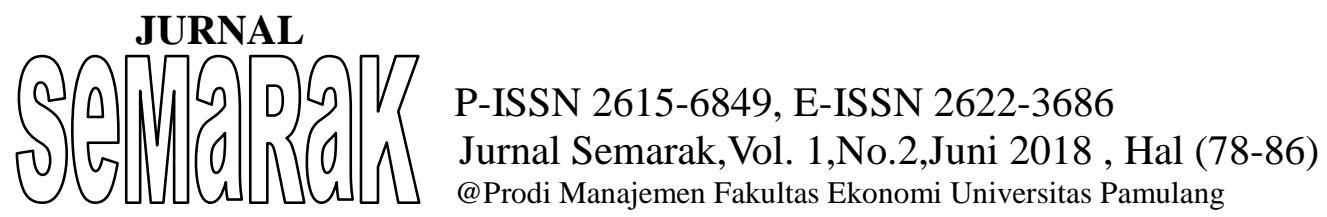

mengajar di sekolah lain sehingga menyebabkan keterlambatan masuk kelas pada saat jam belajar sudah di mulai.

Dalam menyikapi hal di atas maka di katakan bahwa budaya organisasi yang ada di sekolah belum terlaksana secara baik, sekolah sebagai suatu organisasi, dalam sistem pendidikan nasional di Indonesia memiliki peranan strategis untuk menyelenggarakan pendidikan, dalam konteks manajemen sekolah semua kegiatan sekolah harus dikelola dengan memanfaatkan semua sumber daya yang ada untuk mencapai tujuan secara efektif dan efisien. Efektifitas dan efisiensi pencapaian tujuan berarti pembelajaran yang bermuara pada pembelajaran yang menghasilkan output yang berprestasi atau bermutu tinggi.

\section{Kerangka Berpikir}

Kerangka berfikir penelitian ini dapat digambarkan sebagai berikut :

\section{Landasan Teori \\ Budaya Organisasi}

Menurut Peter dalam Pabundu Tika (2014:4) menyatakan bahwa:"Budaya Organisasi adalah pokok penyelesaian masalah-masalah eksternal dan internal yang pelaksanaannya dilakukan secara konsisten oleh suatu kelompok yang kemudian mewariskan kepada anggotaanggota baru sebagai cara yang tepat untuk memahami, memikirkan dan merasakan terhadap masalah-masalah terkait seperti diatas.",

Menurut Shiti dalam Pabundu Tika (2014:4) menyatakan bahwa:"Budaya organisasi adalah seperangkat asumsi dasar dan keyakinan yang dianut oleh anggotaanggota organisasi, kemudian dikembangkan dan diwariskan guna mengatasi masalah-masalah adaptasi eksternal dan integrasi internal."

Menurut Schein dalam Wibowo (2010:16) menyatakan bahwa:"Budaya
Berdasarkan latar belakang masalah yang telah dijelaskan diatas, maka perlu dilakukan suatu kajian dengan judul "Pengaruh Budaya Organisasi Terhadap Kinerja Guru Pada SDN 06 Ciputat".

\section{B. Perumusan Masalah}

Berdasarkan latar belakang diatas, maka permasalahan yang menjadi pokok penelitian adalah sebagai berikut:

1. Bagaimana Budaya Organisasi pada SDN 06 Ciputat?

2. Bagaimana Kinerja guru pada SDN 06 Ciputat?

3. Apakah Pengaruh Budaya Organisasi terhadap Kinerja Guru pada SDN 06 Ciputat?

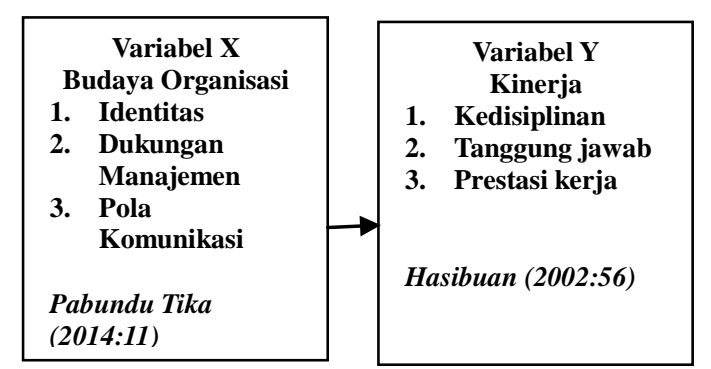

organisasi adalah sebagai filosofi yang mendasari kebijakan organisasi, aturan main untuk bergaul dan perasaan atau iklim yang dibawa oleh persiapan fisik organisasi."

Dari beberapa pengertian budaya organisasi diatas maka penulis menyimpulkan bahwa budaya organisasi adalah filosofi dan seperangkat asumsi dasar yang kegiatannya dilakukan secara konsisten oleh anggota-anggota organisasi yang dirangkai dan dikembangkan untuk mengatasi masalah-masalah yang ada di dalam organisasi maupun diluar organisasi. Kinerja

Menurut Fahmi (2013:2) menyatakan bahwa kinerja adalah: "Kinerja adalah hasil yang diperoleh oleh suatu organisasi baik organisasi tersebut bersifat profit oriented dan non profit 


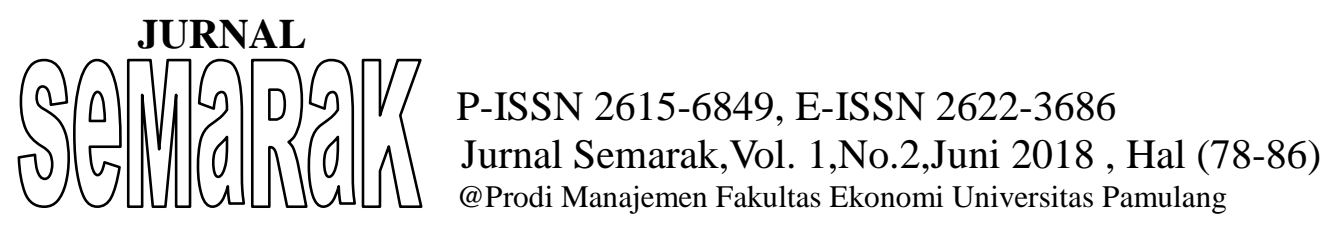

oriented yang dihasilkan selama satu periode waktu."

Baron dan Amstrong (1998) dalam Fahmi (2013:2) menjelaskan bahwa: "Kinerja merupakan hasil pekerjaan yang mempunyai hubungan kuat dengan tujuan strategis organisasi, kepuasan konsumen dan memberikan kontribusi ekonomi."

Menurut Indra dalam Fahmi (2013:2) menyatakan bahwa: "Kinerja adalah gambaran mengenai tingkat pencapaian pelaksanaan suatu kegiatan/program/kebijaksanaan dalam mewujudkan sasaran, tujuan, misi dan visi organisasi yang tertuang dalam perumusan skema strategis suatu organisasi." Dari beberapa pengertian kinerja diatas maka penulis menyimpulkan bahwa kinerja merupakan kekuatan pendorong yang memberi pengaruh terhadap pelaksanaan kegiatan organisasi serta meningkatkan kualitas kinerja yang baik yang dilakukan dengan kerja keras dan kedisiplinan yang tinggi.

\section{Metodologi Penelitian}

Sifat penelitian ini adalah assosiatif kuantitatif. Menurut Sugiyono (2008:5) penelitian assosiatif merupakan penelitian yang bertujuan untuk mengetahui hubungan antara dua variabel atau lebih. Dimana hubungan antara variabel dalam penelitian akan di analisis dengan menggunakan statistika yang relevan atas data tersebut untuk menguji hipotesis

\section{Populasi Dan Sampel}

Dalam penelitian ini yang menjadi populasi adalah 50 orang pada Sekolah Dasar Negeri 06 Ciputat. Sampel dalam penelitian ini adalah berjumlah 50 orang pada Sekolah Dasar Negeri 06 Ciputat.

\section{Analisis Hasil Penelitian dan Pembahasan}

\section{A. Karakteristik Responden}

Karakteristik responden dimaksudkan untuk mengidentifikasi responden, sehingga lebih mudah dalam penganalisaan dan memudahkan pemahaman atas objek dan subjek penelitian. Peneliti telah melakukan penyebaran kuesioner kepada responden pegawai Sekolah Dasar Negeri 06 Ciputat, maka diperolah data sebagai berikut:

\section{Responden Berdasarkan Jenis Kelamin}

\begin{tabular}{|c|c|c|}
\hline $\begin{array}{c}\text { Jenis } \\
\text { Kelamin }\end{array}$ & Frekuensi & Persentase \\
\hline Pria & 16 & $32 \%$ \\
\hline Wanita & 34 & $68 \%$ \\
\hline Jumlah & 50 & $100 \%$ \\
\hline
\end{tabular}

Berdasarkan data yang dikumpulkan peneliti, telah didapat jumlah responden menurut jenis kelamin yaitu, 34 orang berjenis kelamin wanita dengan persentase $68 \%$ dan 16 orang berjenis kelamin pria dengan persentase $32 \%$.

Responden Berdasarkan Usia Pegawai

\begin{tabular}{|c|c|c|}
\hline Usia & Frekuensi & Persentase \\
\hline $19-26$ & 3 & $6 \%$ \\
\hline $27-34$ & 7 & $14 \%$ \\
\hline $35-42$ & 16 & $32 \%$ \\
\hline $43-50$ & 20 & $40 \%$ \\
\hline$\geq 51$ & 4 & $8 \%$ \\
\hline Jumlah & 50 & $100 \%$ \\
\hline
\end{tabular}

Sumber: Data Diolah 2016

Berdasarkan data yang

dikumpulkan peneliti, telah didapat jumlah responden menurut usia yaitu, 3 orang yang berusia $19-26$ tahun dengan persentase $6 \%, 7$ orang yang berusia 27 34 tahun dengan persentase 14\%, 16 orang yang berusia $35-42$ tahun dengan persentase $32 \%, 20$ orang yang berusia 43 - 50 tahun dengan persentase $40 \%$ dan 4 orang yang berusia $\geq 51$ tahun dengan persentase $8 \%$. 


\section{Responden Berdasarkan Tingkat} Pendidikan Pegawai

\begin{tabular}{|c|c|c|}
\hline Pendidikan & Frekuensi & Persentase \\
\hline SLTA & 13 & $26 \%$ \\
\hline D3 & 2 & $4 \%$ \\
\hline S1 & 33 & $66 \%$ \\
\hline S2 & 2 & $4 \%$ \\
\hline S3 & 0 & $0 \%$ \\
\hline Jumlah & 50 & $100 \%$ \\
\hline
\end{tabular}

Sumber: Data Diolah 2016

Berdasarkan data yang dikumpulkan peneliti, telah didapat jumlah responden menurut tingkat pendidikan yaitu, 13 orang yang berpendidikan SLTA dengan persentase $26 \%, 2$ orang yang berpendidikan D3 dengan persentase $4 \%$, 33 orang yang berpendidikan S1 dengan persentase $66 \%, 2$ orang yang berpendidikan S2 dengan persentase $4 \%$ dan yang berpendidikan S3 dengan persentase $0 \%$.

\section{Responden Berdasarkan Masa Kerja} Pegawai

\begin{tabular}{|c|c|c|}
\hline $\begin{array}{c}\text { Lama } \\
\text { Bekerja }\end{array}$ & Frekuensi & Persentase \\
\hline $0-5$ & 7 & $14 \%$ \\
\hline $6-10$ & 15 & $30 \%$ \\
\hline $11-15$ & 9 & $18 \%$ \\
\hline $16-20$ & 5 & $10 \%$ \\
\hline$\geq 21$ & 14 & $28 \%$ \\
\hline Jumlah & 50 & $100 \%$ \\
\hline
\end{tabular}

Sumber: Data Diolah 2016

Berdasarkan data yang dikumpulkan peneliti, telah didapat jumlah responden menurut masa kerja yaitu, 7 orang dengan masa kerja $0-5$ tahun dengan persentase $14 \%$, 15 orang dengan masa kerja 6 - 10 tahun dengan persentase $30 \%, 9$ orang dengan masa kerja $11-15$ tahun dengan persentase $18 \%$, 5 orang dengan masa kerja 16 - 20 tahun dengan persentase $10 \%$ dan 14 orang dengan masa kerja $\geq 21$ tahun dengan persentase $28 \%$.

\section{Budaya Organisasi Pada Sekolah Dasar Negeri 06 Ciputat}

\section{Hasil Data Budaya Organisasi (Variabel X)}

Hasil jawaban dari 50 responden terhadap budaya organisasi. Dari 10 unsur jawaban pernyataan tersebut di analisis dengan menggunakan persentase jawaban diperoleh dari jumlah total jawaban dari masing-masing skala dibagi dengan total keseluruhan jawaban kuesioner, dimana hasil total jawaban adalah $170+271+36$ $+16+7=500$ dan selanjutnya untuk mencari persentase jawaban adalah setiap jumlah pernyataan dikalikan $100 \%$. Berdasarkan jawaban dari seluruh responden yang berjumlah 50 orang dengan 10 pernyataan didapat 170 menjawab "Sangat Setuju" dengan presentase 34\%, 271 menjawab "Setuju" dengan presentase 54,2\%, 36 menjawab "Ragu-Ragu" dengan presentase 7,2 \%, 16 menjawab "Tidak Setuju" dengan presentase 3,2\% dan 7 menjawab "Sangat Tidak Setuju" dengan presentase 1,4\%.

\section{Uji Validitas}

Validitas instrument dalam penelitian ini ditentukan dengan mengorelasikan antara skor yang diperoleh setiap butir pernyataan dengan skor total. Dimana skor total adalah jumlah dari semua skor pernyataan. Rumus yang digunakan untuk mencari nilai korelasi adalah korelasi Pearson Product Moment yang dirumuskan sebagai berikut:

$$
\begin{gathered}
r_{x y}=\frac{n \sum x \cdot x y-\sum x \cdot \sum x y}{\sqrt{(n} \sum x 2-\left(\sum x\right) 2\left(n \sum x y 2-\left(\sum x y\right) 2\right.} \\
r_{x y}=0,409
\end{gathered}
$$

Dengan demikian karena $\mathrm{r}_{\text {hitung }}$ lebih besar dari $r_{\text {tabel }}$ yaitu 0,409 > 0,273 maka dapat disimpulkan bahwa butir pernyataan pada instrument no. 1 budaya organisasi dapat dikatakan valid (dapat digunakan sebagai instrument penelitian), hasil perhitungan validitas instrument pada 


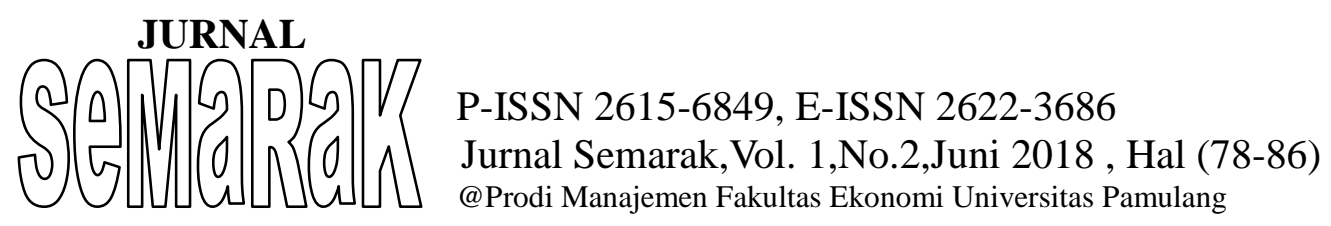

variabel budaya organisasi dapat dilihat bahwa 10 butir pernyataan yang dijadikan sebagai instrument variabel budaya organisasi dikatakan valid karena nilai $r_{\text {hitung }}$ dari masing-masing butir pernyataan lebih besar dari nilai $r_{\text {tabel }}$ pada tingkat alfa (taraf kesalahan) 5\% didapatkan nilai $r_{\text {tabel }}$ sebesar 0,273.

\section{Uji Reliabilitas}

Uji reliabilitas dilakukan untuk mengetahui apakah instrumen yang digunakan peneliti memiliki nilai tetap. Berikut adalah langkah - langkah untuk menguji reliabilitas pernyataan dalam kuisioner:

a. Uji reliabilitas variabel (X)

$$
S_{1}=0,45
$$

Dapat diketahui bahwa nilai varian butir untuk pernyataan nomor 1 yang diberikan kepada responden sebesar 0,45 dan untuk selanjutnya telah dilakukan perhitungan pernyataan keseluruhan instrument variabel budaya organisasi (X) dan jumlah perhitungannya adalah:

$$
\begin{aligned}
& S_{t^{2}}=12,84 \\
& r=0,555
\end{aligned}
$$

Dari hasil data diketahui bahwa jumlah nilai varian butir pada variabel $\mathrm{x}$ sebesar 6,36 sedangkan, nilai varian total adalah 12,84. Dengan rumus product moment, peneliti dapat mengetahui bahwa nilai reliabilitas pada variabel $\mathrm{X}$ adalah 0,555 maka $r_{\text {hitung }}>r_{\text {table }}$ atau $0,555>0.273$ jika

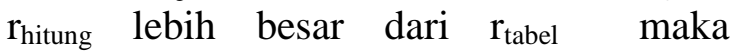
instrument variabel $\mathrm{X}$ dapat dikatakan reliable.

\section{Kinerja Pada Sekolah Dasar Negeri 06 Ciputat}

\section{Hasil Data Kinerja Variabel (Y)}

Hasil jawaban dari 50 responden terhadap kinerja. Dari 10 unsur jawaban pernyataan tersebut di analisis dengan menggunakan persentase jawaban diperoleh dari jumlah total jawaban dari masing-masing skala dibagi dengan total keseluruhan jawaban kuesioner, dimana hasil total jawaban adalah $137+304+37+17+5=500$ dan selanjutnya untuk mencari persentase jawaban adalah setiap jumlah pernyataan dikalikan $100 \%$. Berikut adalah cara perhitungannya:

Berdasarkan jawaban dari seluruh responden yang berjumlah 50 orang dengan 10 pernyataan didapat 137 menjawab "Sangat Setuju" dengan presentase 27,4\%, 304 menjawab "Setuju" dengan presentase 60,8\%, 37 menjawab "Ragu-Ragu" dengan presentase 7,4\%, 17 menjawab "Tidak Setuju" dengan presentase 3,3\% dan 5 menjawab "Sangat Tidak Setuju" dengan presentase $1 \%$.

\section{Uji Validitas}

Validitas instrument dalam penelitian ini ditentukan dengan mengorelasikan antara skor yang diperoleh setiap butir pernyataan dengan skor total. Dimana skor total adalah jumlah dari semua skor pernyataan. Rumus yang digunakan untuk mencari nilai korelasi adalah korelasi Pearson Product Moment yang dirumuskan sebagai berikut:

$$
\begin{gathered}
r_{x y}=\frac{n \sum x \cdot x y-\sum x \cdot \sum x y}{\sqrt{(n} \sum x 2-\left(\sum x\right) 2\left(n \sum x y 2-\left(\sum x y\right) 2\right.} \\
r_{x y}=0,417
\end{gathered}
$$

Dengan demikian karena $r_{\text {hitung }}$ lebih besar dari $r_{\text {tabel }}$ yaitu $0,417>0,273$ maka dapat disimpulkan bahwa butir pernyataan pada instrument no. 1 kinerja dapat dikatakan valid (dapat digunakan sebagai instrument penelitian).

Hasil perhitungan validitas instrument pada variabel kinerja dapat dilihat bahwa 10 butir pernyataan yang 


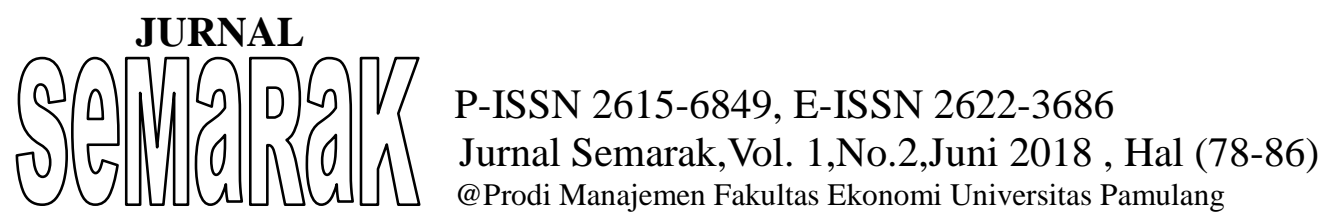

dijadikan sebagai instrument variabel kinerja dikatakan valid karena

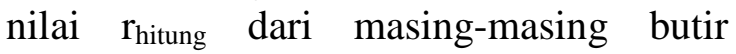
pernyataan lebih besar dari nilai $r_{\text {tabel }}$ pada tingkat alfa (taraf kesalahan) 5\% didapatkan nilai $r_{\text {tabel }}$ sebesar 0,273.

\section{Uji Reliabilitas}

Uji reliabilitas dilakukan untuk mengetahui apakah instrumen yang digunakan peneliti memiliki nilai tetap. Berikut adalah langkah - langkah untuk menguji reliabilitas pernyataan dalam kuisioner:

a. Uji reliabilitas variabel (Y)

Mencari varian butir

$$
S_{1}=1,04
$$

Berdasarkan perhitungan di atas dapat diketahui bahwa nilai varian butir untuk pernyataan nomor 1 yang diberikan kepada responden sebesar 1,04 dan untuk selanjutnya telah dilakukan perhitungan pernyataan keseluruhan instrument variabel kinerja $(\mathrm{Y})$

$$
\begin{aligned}
& S_{t}=13,96 \\
& r=0,662
\end{aligned}
$$

Dari hasil data diketahui bahwa jumlah nilai varian butir pada variabel $\mathrm{Y}$ sebesar 5,63 sedangkan, nilai varian total adalah 13,96. Dengan rumus product moment, peneliti dapat mengetahui bahwa nilai reliabilitas pada variabel Y (kinerja) adalah 0,662 maka $r_{\text {hitung }}>r_{\text {table }}$ atau 0,662>0.273 jika $r_{\text {hitung }}$ lebih besar dari $r_{\text {tabel }}$ maka instrument variabel $\mathrm{Y}$ dapat dikatakan reliable.

\section{Pengaruh Budaya Organisasi Terhadap Kinerja}

\section{Analisis Korelasi Sederhana}

Setelah melakukan uji validitas dan reliabilitas, untuk mengetahui ada tidaknya pengaruh antara budaya organisasi terhadap kinerja pegawai dengan menggunakan koefisien korelasi product moment

$$
r_{x y}=0,643
$$

Berdasarkan hasil perhitungan dengan memakai rumus korelasi product moment, didapati hubungan antara budaya organisasi dan kinerja karyawan sebesar 0,643 dan berdasarkan tabel hubungan korelasi product moment diatas dapat diketahui bahwa pengaruh variabel budaya organisasi $(\mathrm{x})$ terhadap variabel kinerja $(\mathrm{y})$ adalah kuat.

\section{Koefisien Determinasi}

Setelah mengetahui besarnya pengaruh budaya organisasi terhadap kinerja pegawai dengan menggunakan koefisien korelasi, maka selanjutnya dicari koefisien determinasi dengan tujuan untuk mengetahui seberapa besar kontribusi variabel $\mathrm{X}$ terhadap $\mathrm{Y}$, yaitu dengan cara sebagai berikut:

$$
\begin{aligned}
\mathrm{KD} & =r^{2} \times 100 \% \\
& =(0,634)^{2} \times 100 \% \\
& =0,402 \times 100 \% \\
& =40,2 \%
\end{aligned}
$$

Nilai koefisien determinasi tersebut diatas menunjukan bahwa budaya organisasi memberikan kontribusi sebesar 40,2\% sedangkan selebihnya yaitu 59,8\% dipengaruhi oleh beberapa faktor lain yang tidak diteliti penulis.

\section{Uji Regresi Linier Sederhana}

Penelitian ini analisis regresi bertujuan untuk mengetahui seberapa besar pengaruh budaya organisasi terhadap kinerja pegawai pada SDN 06 Ciputat. Salah satu model yang paling mudah untuk 


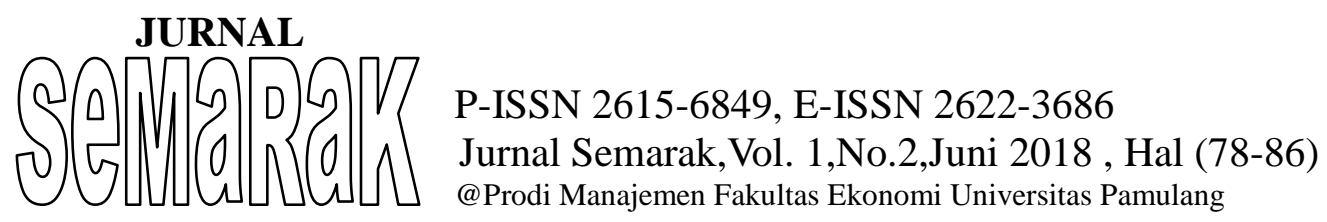

menjelaskan pengaruh itu adalah regresi sederhana yaitu dengan rumus:

$\hat{y}=a+b x$

$\mathrm{b}=\frac{n \Sigma x y-\Sigma x \Sigma y}{n \Sigma x^{2}-(\Sigma x)^{2}} \quad a=\frac{\Sigma y-b \Sigma x}{n}$

$\mathrm{b}=\frac{n \Sigma x y-\Sigma x \Sigma y}{n \Sigma x^{2}-(\Sigma x)^{2}}$

$\mathrm{b}=0,661$

$a=\frac{\Sigma y-b \Sigma x}{n}$

$a=13,53$

a. Persamaan regresi linear sederhana $\hat{\mathrm{y}}=\mathrm{a}+\mathrm{bx}$

$\hat{y}=13,53+0,661(X)$

Berdasarkan hasil perhitungan diatas dapat dilakukan uji signifikan korelasi dengan menggunakan uji $t$ untuk mengetahui apakah budaya organisasi memiliki pengaruh yang signifikan terhadap kinerja, maka rumus uji hipotesis dalam penelitian ini adalah sebagai berikut:

1) Nilai konstanta intercept sebesar 13,53, merupakan hasil nilai konstanta menyatakan bahwa kalau $\mathrm{X}=0$, maka $\mathrm{Y}$ $=13,53$.

2) Nilai koefisien regresi variabel budaya organisasi $(\mathrm{X})$ terhadap variabel kinerja pegawai (Y) adalah sebesar 0,661. Hal ini berarti jika budaya organisasi (X) naik satu-satuan maka akan meningkatkan kinerja sebesar 0,661.

\section{3) Uji Hipotesis}

Ho : $\mathrm{P}=0$ Tidak terdapat pengaruh signifikan antara budaya organisasi terhadap kinerja guru SDN 06 Ciputat.

$\mathrm{Ha}: \mathrm{P}=0$ Terdapat pengaruh signifikan antara budaya organisasi terhadap kinerja guru pada SDN 06 Ciputat. $\mathrm{t}=\frac{r \sqrt{n-2}}{\sqrt{1-r^{2}}}$

Hasil $t_{\text {hitung }}$ tersebut selanjutnya dibandingkan dengan hasil $t_{\text {tabel }}$. Untuk kesalahan 5\% dan dk : n-2 = 50 - $2=48$, maka diperoleh $t_{\text {tabel }}(2,010)$. Jadi dari hasil perhitungan uji hipotesis di atas maka dapat dilihat bahwa, $t_{\text {hitung }}>t_{\text {tabel }}$ atau 5,875 > 2,010 maka menunjukan hasil yang signifikan atau dengan kata lain $t_{\text {hitung }}>t_{\text {tabel}}$, maka $\mathrm{H}_{\mathrm{a}}$ diterima Ho ditolak, yang berarti bahwa terdapat pengaruh yang signifikan antara budaya organisasi terhadap kinerja guru pada SDN 06 Ciputat.

\section{G. Kesimpulan}

Berdasarkan hasil penelitian dan pembahasan mengenai variabel budaya organisasi dan kinerja pada Sekolah Dasar Negeri 06 Ciputat, maka penulis menyimpulkan sebagai berikut:

1. Dilihat dari gambaran indikatorindikator masing-masing variabel, menunjukan bahwa sebagian besar responden cenderung memberikan nilai tinggi terhadap indikatorindikator dari variabel budaya organisasi. Ini berarti bahwa budaya organisasi pada Sekolah Dasar Negeri 06 Ciputat dapat dikategorikan baik. Hal ini dapat dilihat dari hasil kuesioner responden yang menjawab pernyataan sangat setuju dengan persentase $34 \%$ dan setuju dengan persentase $54,2 \%$.

2. Demikian pun hasil kuesioner kinerja para pegawai atau responden sebagian besar cenderung memberikan jawaban dengan pilihan kategori baik terhadap indikatorindikator dari variabel kinerja pegawai artinya para pegawai Sekolah Dasar Negeri 06 Ciputat memiliki kinerja dengan kategori tinggi. Hal ini dapat dilihat dari hasil kuesioner responden yang menjawab 
pernyataan sangat setuju dengan persentase $27,4 \%$ dan setuju dengan persentase $60,8 \%$.

3. Setelah dilakukan uji validitas dan uji reliabilitas untuk mengetahui ada tidaknya hubungan antara pengaruh budaya organisasi dan kinerja dapat dilihat dari uji analisis korelasi sederhana yang didapati hubungan yang kuat antara budaya organisasi terhadap kinerja sebesar 0,643. Berdasarkan nilai koefisien determinasi menunjukan bahwa budaya organisasi memberikan kontribusi sebesar 40,2\% sedangkan selebihnya yaitu 59,8\% dipengaruhi oleh beberapa faktor lain yang tidak diteliti penulis dan untuk mengetahui seberapa besar pengaruh budaya organisasi dan kinerja dapat dilihat dari uji regresi linear sederhana yaitu telah di dapati hasil $\hat{y}=13,53+$ 0,661 (X). Hasil dari perhitungan uji hipotesis menunjukkan hasil yaitu $t_{\text {hitung }}>t_{\text {tabel }}$ atau 5,875 $>2,010$ maka menunjukan hasil yang signifikan atau dengan kata lain $t_{\text {hitung }}$ lebih besar dari $t_{\text {tabel }}$, yang berarti bahwa terdapat pengaruh yang signifikan antara budaya organisasi terhadap kinerja guru pada SDN 06 Ciputat. $\begin{array}{ccr}\text { Herlambang, } & \text { Susatyo. } & \text { Pengantar } \\ \text { Manajemen: } & \text { Cara } & \text { Mudah } \\ \text { Memahami } & \text { Ilmu } & \text { Manajemen. } \\ \text { Yogyakarta: } & \text { Gosyen } & \text { Publishing, } \\ \text { 2013. } & & \end{array}$

Mangkunegara, Anwar Prabu. Manajemen Sumber Daya Manusia Perusahaan. Bandung: Remaja Rosdakarya, 2013.

Sugiyono. Metode Penelitian Kuantitatif, Kualitatif dan $R \& D$. Bandung: Alfabeta, 2011.

Sulistiyani, Ambar Teguh dan Rosidah. Manajemen Sumber Daya Manusia. Yogyakarta: Graha Ilmu, 2003.

Sunyoto, Danang. Manajemen Sumber Daya Manusia. Yogyakarta: Center for Academics Publishing Service, 2012.

Tika, Moh. Pabundu. Budaya Organisasi dan Peningkatan Kinerja Perusahaan. Jakarta: Bumi Aksara, 2014.

Wibowo. Budaya Organisasi: Sebuah Kebutuhan Untuk Meningkatkan Kinerja Jangka Panjang. Jakarta: Rajawali Pers, 2010.

\section{Daftar Pustaka}

Fahmi, Irham. Manajemen Kinerja Teori dan Aplikasi. Bandung: Alfabeta, 2013.

Handoko, T. Hani. Manajemen Personalia dan Sumber Daya Manusia. BPFE Yogyakarta, 2014.

Hartatik, Indah Puji. Buku Praktis Mengembangkan SDM. Yogyakarta: Laksana, 2014.

Hasibuan, Malayu S.P. Manajemen Sumber Daya Manusia. Jakarta: Bumi Aksara, 2002. 